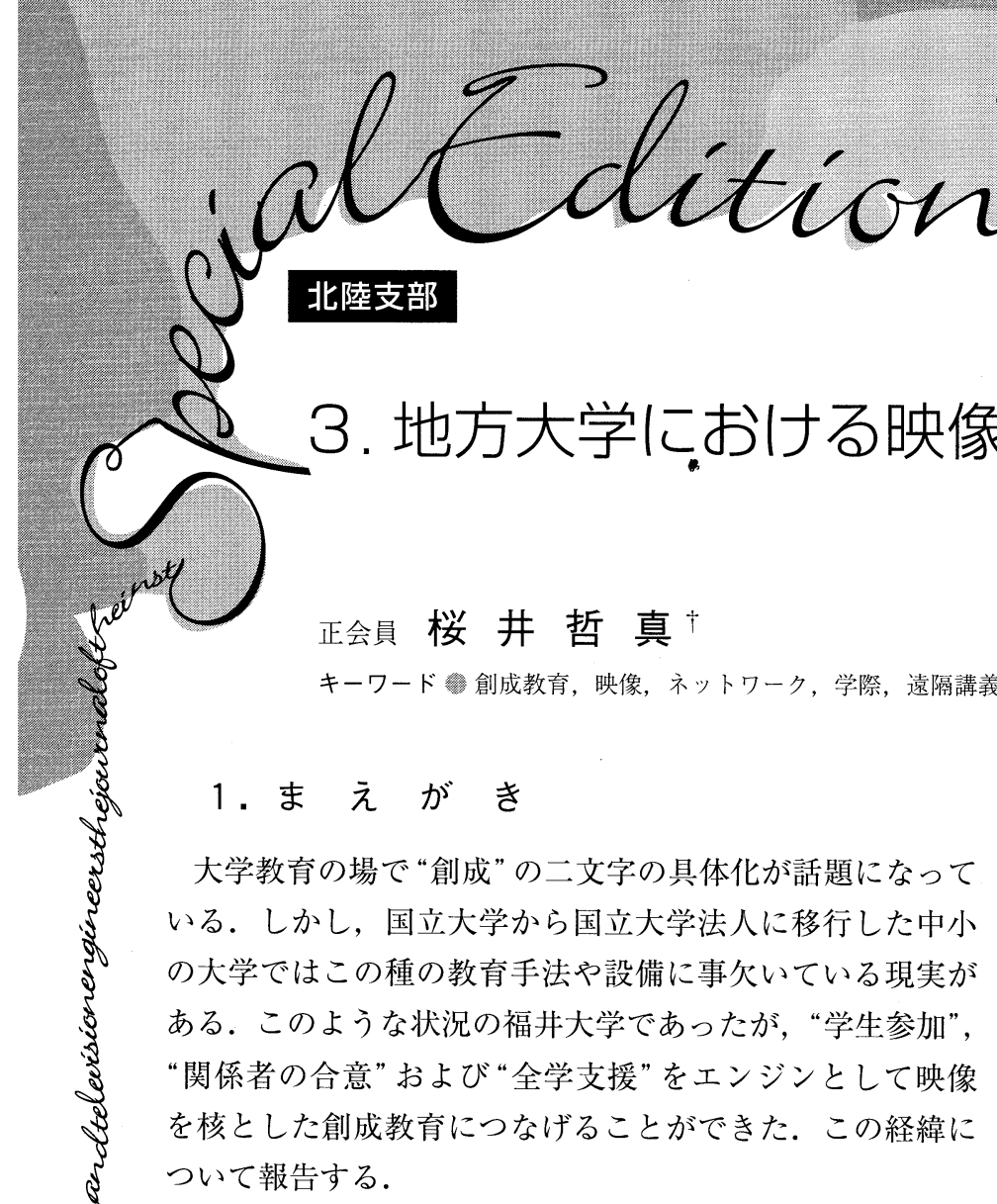

\section{2. 大学におけるディジタル映像技術環境}

福井大学において, 旧情報工学科を再編して情報・メデ イア工学科が誕生したのは1999年 4 月のことである.この数 年前には, 動画像の効率的な圧縮・伸展を可能とした MPEGの標準化, ネットワーク機能と動画像表示機能を併 せ持つPC用OSの市販がなされていた。 また，アナログで 映像を記録する $16 \mathrm{~mm}$ フィルム，35mmフィルムに加えて， ディジタルビデオ (以下, DVと表記) テープ, ハードディ スクあるいはCD/DVDなどのディジタル記録メディアが安 価に入手可能な状況があった。 さらに，10万円を切る価格 のハードウェアでメディアからコンピュータに映像情報を 取込むことも可能となっていた. この結果, 2000年前後に は，100万円程度の費用でディジタル技術を核とする映像創 成の教育や研究を可能とする環境が大学などにあった。

一方，1999年には次世代ネットワークと称された日本ギ ガビットネットワーク (JGN)の運用が開始された.しかし, 福井大学 (福井県) にはそのアクセスポートが設けられてお らず，設置の順番を待つ身であった.

\section{2. 動画像通信技術との出会い}

幾つかの出来事が一つの大きなうねりを福井大学に作り 出すきっかけとなった. まず, 2000年9月には福井大学に JGNのアクセスポートが設けられた. 予算不足で, 近隣の 大学などから借用したユニットを用いて遠隔地との動画像 通信を行うことしかできなかったが，それだけでも充分な

\section{†福井大学 大学院 工学研究科 情報・メディア工学専攻}

"Interdisciplinary Education with Contents Creation in University of Fukui" by Tetsuma Sakurai (University of Fukui, Fukui)
魅力を学生や教職員に感じさせる体験であった.

逆説的に聞こえるかもしれないが，幸運にもJGN引込み 時の研究費補助がなかったため, 借り物の通信ユニットの 初期設定や通信路の確立に必要な実務作業は毎回, 教職員 と学生で行う必要があった. これらの作業は当時, 大変な 負担と感じたが, 結果として学内に動画像通信の実務知識 が蓄えられ，この分野のエキスパートを生み出す研修の場 となった。

遠隔地との動画像通信が可能なJGNという舞台はある. 技術は手にした。ないものはネットワークに流すコンテン ツであった。著作権の関与するテレビ番組やスポーツ中継 を取込むことは論外であり，気兼ねすることなくネットワ ークに流せる実験・研究用の動画像コンテンツが欲しい, と思う毎日であった.

同じ時期, 大学教員の授業改善 (Faculty Development) に関わるさまざまな試みが検討されていた．「教員の講義 模様を録画してネットワーク公開のコンテンッとする」, 「自らの録画講義を後で教員が見てFDの一助とする」とい う二つのアイディアが結びついたのは，2000年の後期に開 催された情報・メディア工学科の教室会議であった. 会議 では多彩な意見が飛び交ったものの, “関係者の合意”で学 科全教員の授業あるいは実験をディジタルメディアやネッ トワークで公開することとなった。

修士論文などの研究に必要な実験用動画像コンテンツを 必要としていた学生諸君がこれに反応した。数人の学生が チームを作って学科全教員の講義を撮影し，ネットワーク に公開し, 併せて, ディジタルビデオディスクでも配布す る一連の出来事が瞬く間に行われた．学生諸君の撮影やネ ットワーク配信の腕が上がった頃，学会および文部省（当 時)の支援で, 北陸地区では初めての高校生向けのIT講習 会を開催することとなった。いくつかの講習テーマが実施 されたが，大きな関心を集めたものがネットワークを介し た遠隔実験授業であった．数万円のヘッドマウントカメラ とマイクを装着した大学院生が, 離れた教室の高校生の指 示を生かした機材操作で光速の測定実験を披露するなど, 予算がない中での遠隔動画像通信の利点をクローズアップ する試みであった.

学科全員の授業の公開，ネットワークを介した高校生へ 
の実験授業の提供など，どのような経緯でだれが発案者か 定かでなくなっているが, 当時としては大学の教育の手法 として耳目を集めるものがあった，全国紙や公共テレビ放 送などが, 福井大学の試みを大きく何度も取り上げてくれ るという幸運に浴した，先の授業録画ビデオディスクは， 総計で400枚以上を日本全国の大学や高校に送らせてもら うこととなった．JGNが引かれたことで県内のメデイアが 好意的だったこともあるが，2000年から2001年の学生諸君 の活躍は驚くべきもので，1ヶ月に一度はなんらかのメデ イアでその活動が紹介されていた。これらのことが大学の 知名度を上げたため, 中心となった学生は福井大学学長表 彰を受けた，彼を中心とするチームはこれを機に全学の支 援を受けるようになり，その活動の幅の広がりとともに学 生を核とした創成教育のサイクルが内部エネルギーで自転 し始めた。

\section{3. 大学における創成教育への展開}

学内に蓄積された動画像コンテンッの制作・通信技術が 創成教育につながった経緯について述べる.

まず，教育技法，ツールとしてのメディアに着目した取 組が，2001年に情報・メディア工学科のメディア情報学実 践厂してスタートした．これに加えて，PCによる映像操 作技術に未熟な他の学部生を対象とする授業も“工学部学 際実験”として2003年から始まっている．参加学生全員を 複数のチームに分けてビデオ作品を制作する取組であり, ビデオ制作会社と交流がある教員がいて，シナリオの書き 方や撮影の最小限のテクニックを授業に持ち込むことがで きた．これも学生の興味を掻き立てる助けとなった．専門 の映画撮影班なみに, ディレクタから始まって記録掛まで, 一人一人が作品制作に貢献する枠組を授業・実験の中心に 据えた、インセンティブを与えるために，印象に残った作 品を学生が互選して, 毎年, ネットワーク上に公開してい $ろ^{1)}$.

当初の予想では情報・メディア工学科生の独走かと思わ れたコンテンツ競作であるが, いくつかの予想されなかっ た効果を生み出した，例えば，図1は，建築建設工学科の学 生チームがコンテンツ制作に必要な数字を表現した1コマで ある。流麗な動きと色彩で数字を飾ることに長けた情報・ メディア工学科生諸君が文字通り, “違った視点でものを見 る”ことの必要性を学んだ表現の一つである。この講義は

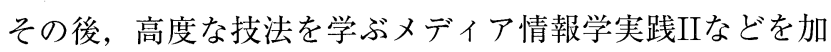
え, 入学早々の学生にデイジタル処理技術のおもしろさや 怖さ (映像の偽造や知的財産権の侵害など) などを教授し, 併せて倫理感を䁔成する重要なカリキュラムの一つになっ ている．2005年には福井県内で開催される文化庁メディア 芸術祭へ向けた大学としての取組も始まっている.

地域貢献にも大学発のメディアが貢献している．地方都 市の駅前は郊外の大型店に押されて空洞化しつつある。そ

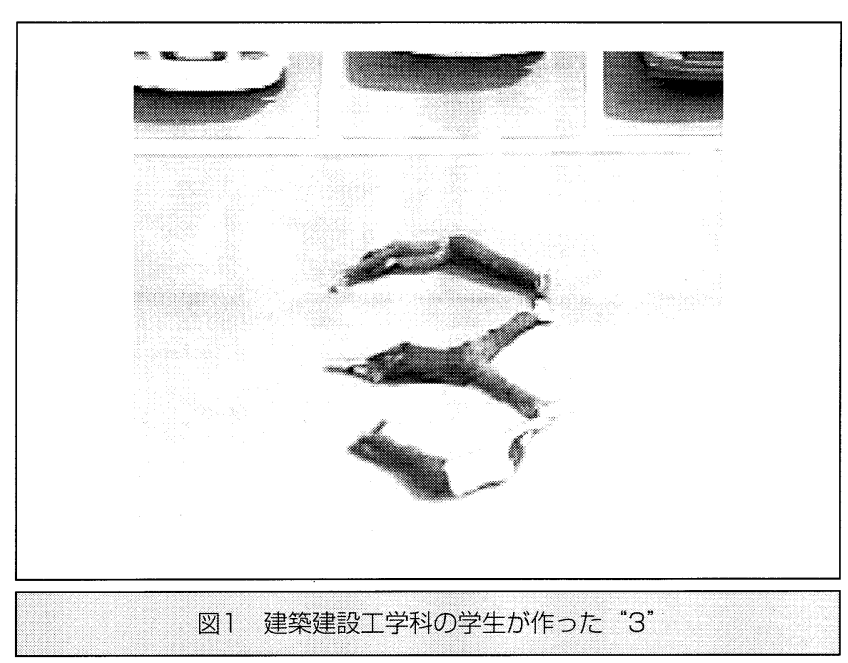

んな駅前商店街のリーダーの方から客寄せ大型ビジョンへ の映像コンテンツ供給の依頼があった. 商店街の負担が大 きい有料番組の放送から教育の副産物として生まれている 福井大学の学生コンテンツに切替えたいとのことであっ た. 鑑賞に堪えうる幾つかの作品を提供するうちに, 両者 の信頼関係が深まり，2005年度からは学生が駅前商店街の PRビデオを制作するまでになった。

\section{4. 動画像通信・コンテンツ制作で出会う不思議}

福井大学にはネットワークトラフィックの輻輳実験に用 いるQoS制御可能なスイッチがないので, 学生達は複数の サーバ/クライアントペアの数 (コネクション数)を変える ことで実験のための帯域制御を行っている．映像配信・鑑 賞のためのプレーヤ(ソフトウェア) を, 複数組のサーバ/ クライアント端末にインストールして対応するコネクショ ン毎にファイルの要求・送信を行う設定とし, 稼動コネク ション数を増すことでネットワークの輻輳度を上げていっ た。すると， R社のプレーヤが帯域を占有する前に送受信 を自己規制してしまうことに気付いた (図2).ネットワー クが貧弱な時代には必要であったかもしれないが，带域が 充分な現在ではネットワークの管理者に誤ったネットワー ク設計指針を与えてしまいかねない仕組みである. 販売元 でもそのような機能に気付かれていなかったようで学生の お手柄である.

もう一つ，気になる「はてな？」を指摘しておこう．JGNIIやSinetなどの公共ネットワークを用いた動画像双方向通 信による大学間の授業共有が推進されている2). しかし, これらのネットワークにつなぐ足回り回線やノードまでの 回線の帯域はお怙むね100Mbpsである。このような帯域で はハイビジョン品質の動画像を流すとネットワークに大き な影響が生じる。学内のネットワークPCによる簡単なモデ ル実験で得られた伝送量変化の一例を図3に示したＵDP である30Mbpsの動画像トラフィックの発生とともに汎用 的なhtml系のトラフィックが不安定になっていることが読

(19) 1395 


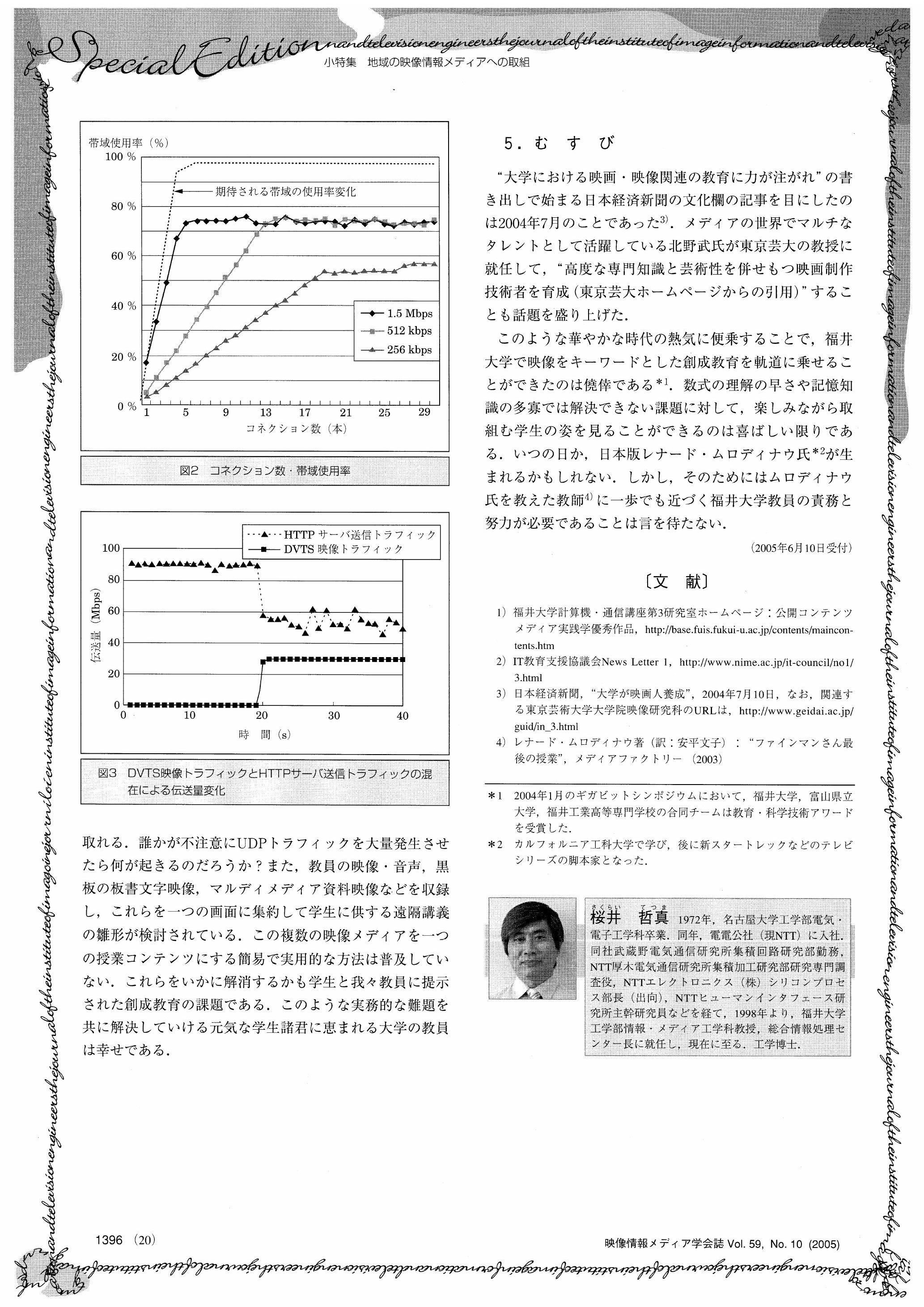

